\title{
Biological removal of cadmium by Alcaligenes eutrophus $\mathrm{CH} 34$
}

\author{
${ }^{1 *}$ A. H. Mahvi and ${ }^{2}$ L. Diels \\ ${ }^{1}$ Department of Environmental Health Engineering, School of Public Health, Center for Environmental Research,
}

Tehran University of Medical Sciences, Tehran, Iran

${ }^{2}$ Felemish Institute of Technological Research, V.I.T.O., MOL, Belgium

\begin{abstract}
Some bacteria like the heavy metal resistant Alcaligenes eutrophos CH34strains are able to promote biomineralization, being the biologically induced crystallization of heavy metals. In the presence of heavy metals, this strain may create an alkaline environment in the periplasmic space and outer cell environment appropriate induction of heavy metals resistance mechanisms. In such an environment metal hydroxides are formed together with metal bicarbonates resulting from the carbonates production by the cell. Also metals bind to out cell membrane proteins and the metal hydroxides and bicarbonates precipitate around these nucleation foci inducing further metal crystallization. A pilot-plant was set up in which Alcaligenes eutrophus CH34 were inoculated and reproduced in a composite membrane, based on polysulfone. The membrane is casted on a polyester support. The biological membrane was in continuous contact with nutrients from inside and the other side was in contact with wastewater flow containing $120-\mathrm{mg} / \mathrm{l}$ cadmium. Nutrients are used for growth and reproduction of bacteria and for development of bacteria resistance agents against heavy metals. At the effluent side immobilized bacteria induce metal precipitation and metal crystals. A column, which was in continuous contact with treated effluent, was continuously filled with glass bends to which the metal crystals bind and grow. The efficiency for $\mathrm{Cd}$ removal was over 99 percent. Cd removal could be recovered from the recuperation column by acid treatment without damaging the bacteria.
\end{abstract}

Key words: Alcaligenes eutrophos CH34, cadmium removal, biomineralization, polysulfone membrane, crystallization, industrial wastewater

*Corresponding Author, E-mail: ahmahvi@yahoo.com

\section{Introduction}

Recuperation of heavy metals can be realized by different techniques in function of their concentration. High concentration (>500 ppm) can be removed by electrolysis and low concentration $(<500 \mathrm{ppm})$ can be removed by biosorption or ion exchange columns. At concentrations between 500 and $5 \mathrm{ppm}$ precipitation with lime is possible generating high volumes of sludge with low metal/sludge ratios (Diels, et al., 1994). Biomineralization is a process in which bacteria actively induce the precipitation foci on their cell surface (Diels, 1990 and Michel et al., 1986). Bacteria, which are resistant to heavy metals and to oxyanions, were the subjects of numerous studies, which relay on various disciplines from microbial ecology to molecular biology. Alcaligenes were found in sediments or soils with a high content of heavy metals (zinc, cobalt, copper and cadmium in Belgium and Zaire). Samples from such places may contain up to $5-10 \%$ of these metals and still provide viable bacterial contents.
Most of Alcaligenes eutrophus strains share the following characteristics with: growth at the expense of a variety of organic substrates with the exclusion of sugars, oxidative metabolism, facultative chemolithotrophy, and presence of megaplasmids carrying heavy metals resistance genes (Collard, et al., 1993). The aerobic gramnegative bacterium Alcaligenes eutrophus $\mathrm{CH} 34$ contains two large plasmids that confer resistance to several heavy metals (Cooksey, 1993). PMOL28 is resistance to $\mathrm{Co}^{2+}, \mathrm{Ni}^{2+}$, $\mathrm{CrO}_{4}{ }^{2-}, \mathrm{Hg}^{2+}$ and $\mathrm{Ti}^{+}$and pMOL30 resistance to $\mathrm{Cd}^{2+}, \mathrm{Co}^{2+}, \mathrm{Cu}^{2+}, \mathrm{Zn}^{2+}, \mathrm{Hg}^{2+}$ and $\mathrm{Ti}^{+}$(Diels and Mergeay, 1990). In the plasmid pMOL30, the CZC gene cluster ensures resistance to $\mathrm{Cd}^{2+}$, $\mathrm{Co}^{2+}$ and $\mathrm{Zn}^{2+}$ (Nies, et al., 1989). This gene cluster includes the operon (structural genes), upstream of which a regulatory region is located. When compared with the sequences of corresponding putative proteins, the strongly hydrophilic czcA emerges as a transmembrnae protein, which ensures a cation/protein 
anitiporter efflux. In association with $\mathrm{czcB}$ and czcC, czcA allows the efflux of heavy metal ions. On pMOL28, the structural genes cnrCBA correspond to the structural czc CBS genes. Figure 1 shows the similarity of cnrCBA and czcCBA gene products (Collard, et al., 1994). Figure 2 shows the efflux cation system and how heavy metals enter and exit from cells.

Figure 3 shows the colonization of bacteria in function of time and in Figure 4 bacterial induced formation $\mathrm{Cd}^{2+}$ crystals on membrane was presented (Diels, et al., 1994). The glass bead columns are utilized tp trap and remove the bacterial formed $\mathrm{Cd}\left(\mathrm{HCO}_{3}\right)_{2}$ and $\mathrm{CdCO}_{3}$ crystals. The growth of $\mathrm{Cd}\left(\mathrm{HCO}_{3}\right)_{2}$ and $\mathrm{CdCO}_{3}$ on the glass beads was presented in Figure 5.

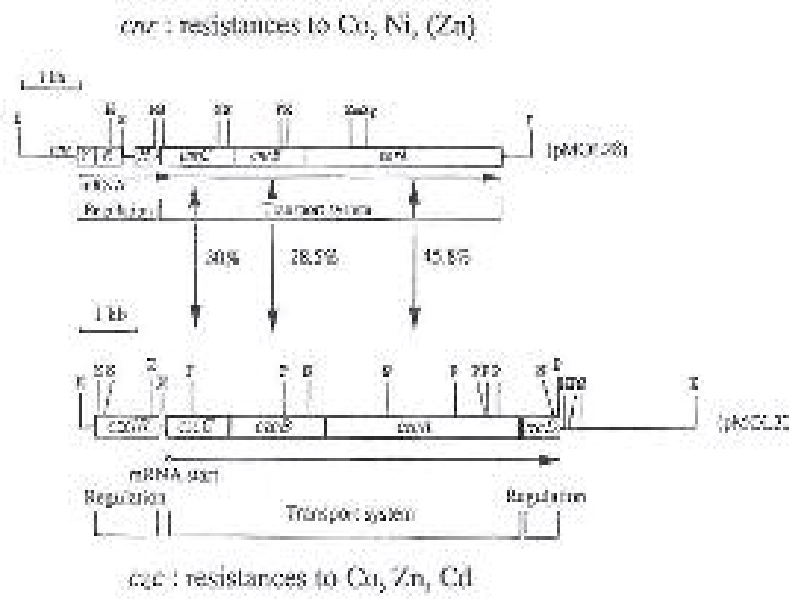

Figure 1: Organization of czc and cnr operons of A. eutrophus $\mathrm{CH} 34$

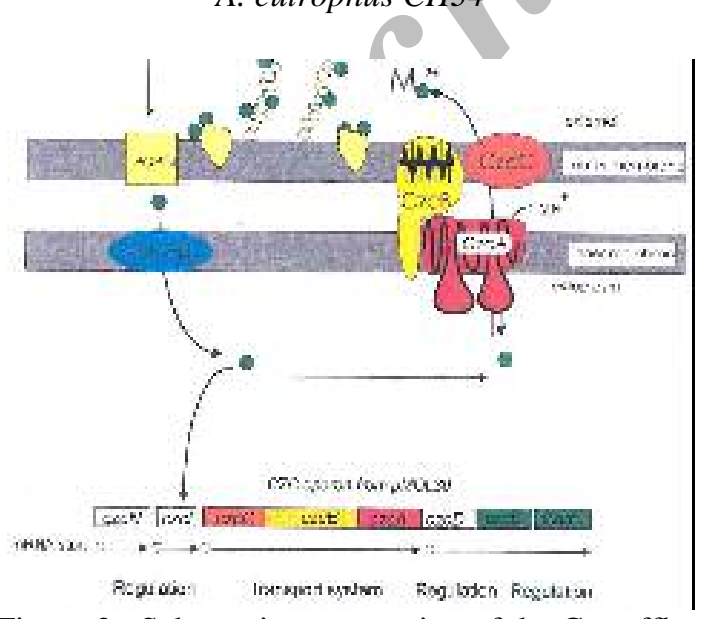

Figure 2: Schematic presentation of the Czc efflux system and a working model for heavy metal uptake, processing by efflux, and post efflux metal fixation on polysaccharides and proteins
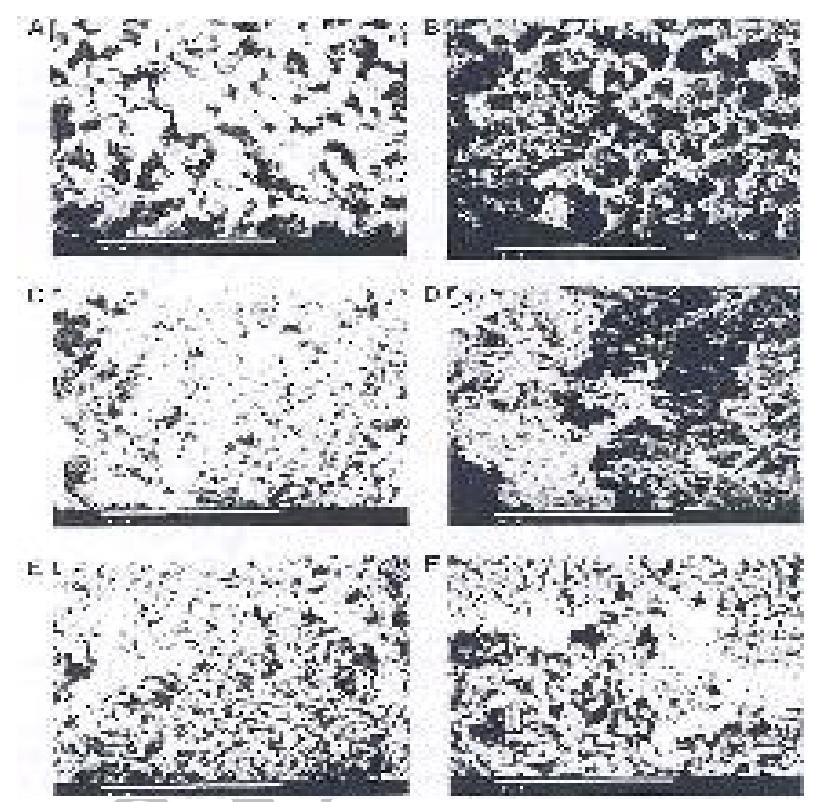

Figure 3: Immobilization and colonization of $A$. eutrophus on plyslofone membrane. Before filtration (A), just after filtration (B), after 3 days (C), after 6 days (D), after 8 days (E), and after 10 days (F). The bar presents $10 \mu \mathrm{m}$.

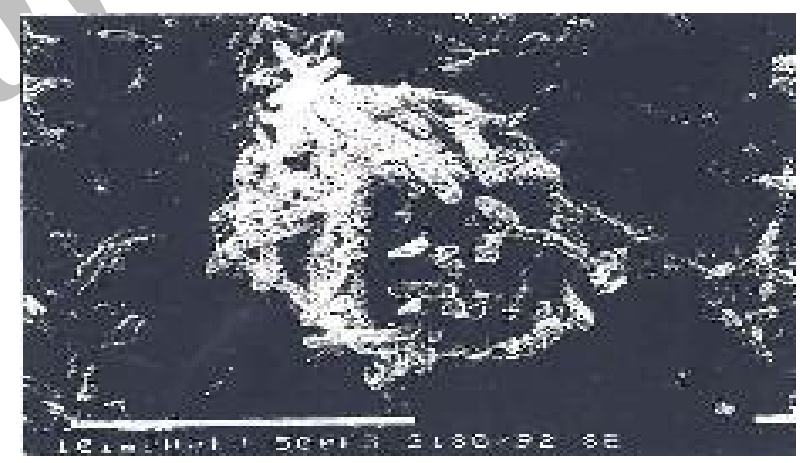

Figure 4: bacterial induced formation of $\mathrm{Cd}^{2+}$ crystals on polysolfone membrane. The figure presents the bacterial formed $\mathrm{Cd}\left(\mathrm{HCO}_{3}\right)_{3}$ and $\mathrm{CdCO}_{3}$ crystals.

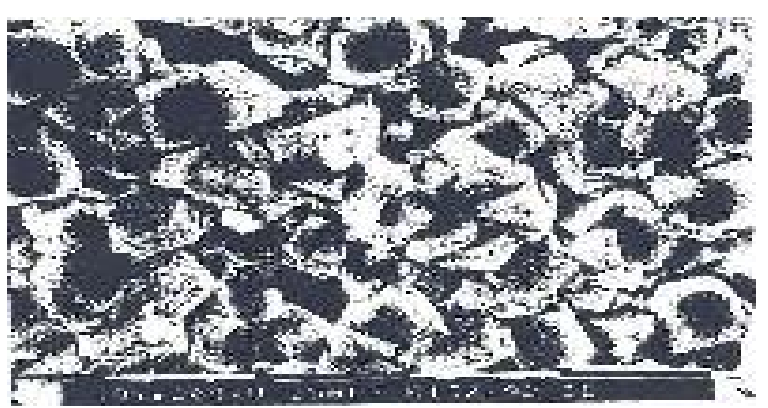

Figure 5: $\mathrm{Cd}^{2+}$ crystal formation on the glass bead column. The figure presents the bacterial formed crystals on the glass beads. The white or black bar presents $10 \mu \mathrm{m}$. 


\section{Materials and Methods}

A pilot-plant reactor for biological removing of $\mathrm{Cd}^{2+}$ was set up. A. eutrophus $\mathrm{CH} 34$ is immobilized on a polysulfone membrane. A reaction chamber was composed of two stainless steel cylinders mounted on each other and had two inlets and two outlets. A polysulfone membrane covered with the polyester active membrane at the inner surface separated the cylinders. The pore diameters were $1 \mu \mathrm{m}$ on one side and the other side had a pore diameter of 5 $\mu \mathrm{m}$. The membrane had a thickness of $150 \mu \mathrm{m}$ and the thickness of the former pore was 100 $\mu \mathrm{m}$. After colonization of bacteria on whole side of the polysulfone membrane, the pilot-plant reactor was operated for wastewater treatment. 1 $\mathrm{mM} \mathrm{CdCl}{ }_{2}$ was added to produce an effluent with a concentration of about $120 \mathrm{ppm}$ of $\mathrm{Cd}$. The following nutrient mediums were used in this study:

\begin{tabular}{|c|c|}
\hline glycophosphate & 294 \\
\hline $\mathrm{NH}_{4} \mathrm{NO}_{3}$ & 1000 \\
\hline $\mathrm{MgSO}_{4} \cdot 7 \mathrm{H}_{2} \mathrm{O}$ & 200 \\
\hline $\mathrm{FeSO}_{4} \cdot 7 \mathrm{H}_{2} \mathrm{O}$ & 10 \\
\hline Acetate & 8000 \\
\hline $\mathrm{CaCl}_{2} \cdot 2 \mathrm{H}_{2} \mathrm{O}$ & 10 \\
\hline
\end{tabular}

The effluent enters the reactor; has a contact with polysulfone membrane; and exit the reactor from outlet side. Through the opposite side a nutrient stream to keep the bacteria metabolizing flows into the reactor and without any contact with effluent leaves it. Solutions were pumped at a flow-rate of $15 \mathrm{ml} / \mathrm{min}$ for the raw wastewater containing $\mathrm{Cd}$ and $30 \mathrm{ml} / \mathrm{min}$ for the nutrient. Since each chamber had a known volume, the effluent was discharged at a same flow rate. After leaving the reactor, the effluent to be treated, passes over a column, bearing glass beads, before it recalculates to the effluent flask.

The precipitates of $\mathrm{CdCO}_{3}$ and $\mathrm{Cd}(\mathrm{OH})_{2}$ were trapped on the glass beads. The pilot was set up and run for eight weeks. It took about 2-3 weeks for pilot plant to be stabilized. The samples were taken twice a week. Similarity in results will represent the stabilized conditions.

Figure 6 provides the schematic presentation of the pilot-plant reactor. It was used to treat effluents containing $\mathrm{Cd}^{2+}$ in a continuous way.

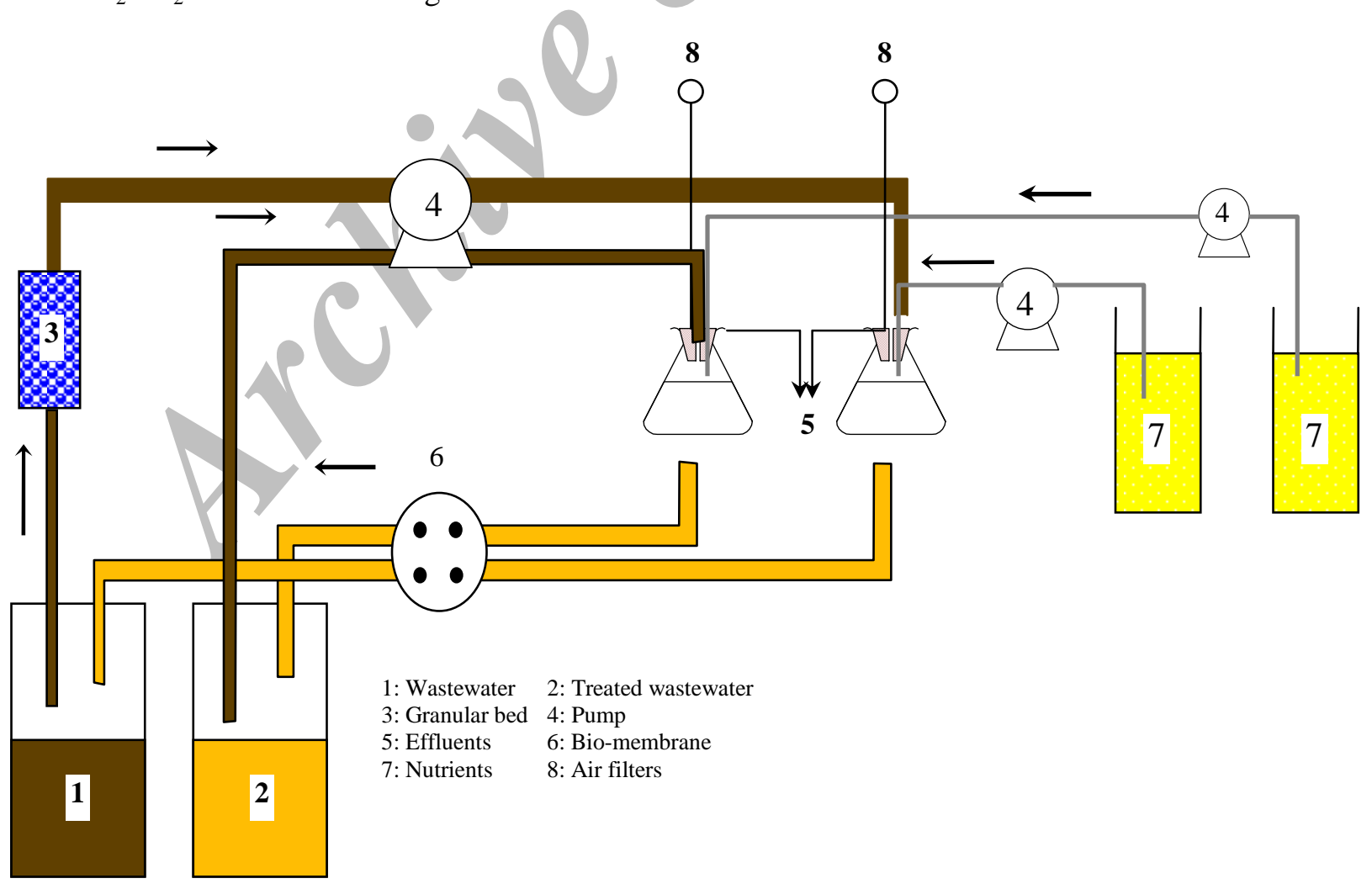

Figure 6: Flow diagram of a flat sheet reactor 
The main purpose of this study is to remove cadmium from industrial wastewater by eutrophus CH34 bacteria on polysulfone membrane.

This study has been done in Felemish Institute of Technological Research, V.I.T.O., MOL, Belguim in 1999.

\section{Results}

The pilot was operated for a week without addition of wastewater in order to colonize A. eutrophus $\mathrm{CH} 34$ on the polysulfone membrane.

At first glance, it was not obvious how the efflux cations (i.e. transport and maintenance of cations outside the cytoplasma) as a main mechanism of resistance would lead to a process of bioremediation. In fact, it was observed in cultures of Alcaligenes eutrophus CH34 grown in the presence of $\mathrm{Cd}^{2+}$, which the $\mathrm{Cd}^{2+}$ concentration in the supernatant decreased drastically in late log phase. The $\mathrm{Cd}^{2+}$ concentration in the culture was reduced from $200 \mathrm{ppm}$ to $2 \mathrm{ppm}$ and the $\mathrm{Zn}^{2+}$ concentration from $600 \mathrm{ppm}$ to $10 \mathrm{ppm}$. This effect was always accompanied by a $\mathrm{pH}$ increase (up to 9) and an important precipitation of carbonates and hydroxides (Diels et al., 1993). The precipitation seemed to be initiated around bacterial cells, which under the scanning microscope looked to be coated with crystals, and continued into the culture of the antiporter efflux system, where the bacterial cell accumulated hydrogen ions in exchange for the extrusion of cations (Collard et al., 1994). To avoid any shock, raw wastewater gradually flowed into reactor. After 3 days and being assured that steady-state was provided, samples were taken in function of time and metal concentration measured. Since $\mathrm{pH}$ of the

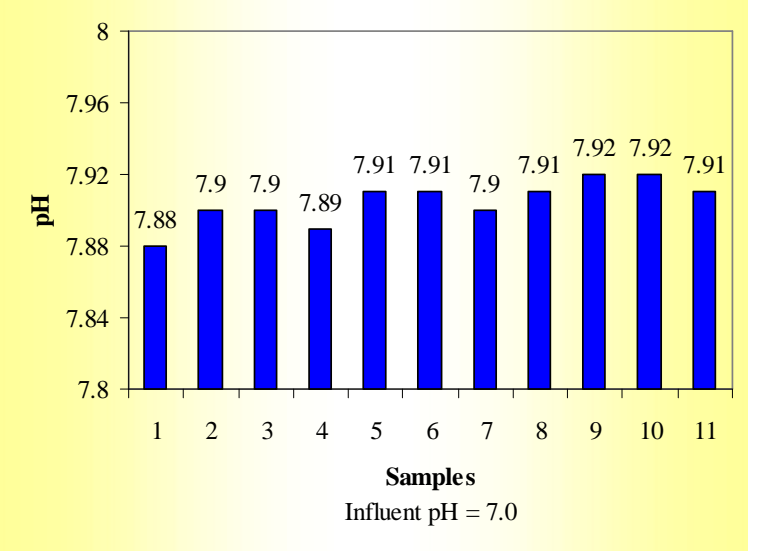

Figure 7: Effluent $\mathrm{pH}$ in various samples solution increased to a level of about 9 , it was assured that the crystal of carbonate, bicarbonate and hydroxide of cadmium would occur in alkaline condition (Figure 7). The turbidity tests that were carried out on the wastewater and nutrient solution indicated bacterial growth in the system. Biological removal of $\mathrm{Cd}\left(\mathrm{HCO}_{3}\right)_{2}, \mathrm{CdCO}_{3}$ and $\mathrm{Cd}(\mathrm{OH})_{2}$ on the glass beads that is resulted in the color and shape change of them. $\mathrm{Cd}^{2+}$ content was measured by the atomic adsorption indicated a significant decrease of $\mathrm{Cd}^{2+}$ concentration $(0.1$ $\mathrm{mg} / \mathrm{l}$ ) in the effluent (Figures 8-10). $\mathrm{Cd}^{2+}$ removal efficiency was calculated about 99 percent for this reactor. Figures 9 and 11 show removal efficiency of $\mathrm{Cd}^{2+}$ in the reactor.

The results of effluent $\mathrm{pH}$, percentage of $\mathrm{Cd}^{2+}$ removal, the concentration of $\mathrm{Cd}^{2+}$ in the effluent or in the nutrient side in Figures 7-11 show that the system was not stabilized at first and after 2-3 weeks it had been stabilized.

\section{Discussion and Conclusion}

A through physiological study of this biochemical reactions resulting in bioprecipitation of $\mathrm{Cd}^{2+}$ salt crystals on the beads and the reduction of $\mathrm{Cd}^{2+}$ concentration from the influent wastewater, with maintaining the $\mathrm{pH}$ regulation during the expression of heavy metal resistance mechanisms, helps the improvement of bioremediation processes that are the basic functions of these bacteria for metal fixation.

Different potential fields of applicability's can be emphasized for heavy metal resistively of Alcaligenes eutrophus CH34. The development of bioreactors in which bacteria can be immobilized, could be in the pores of the membrane.

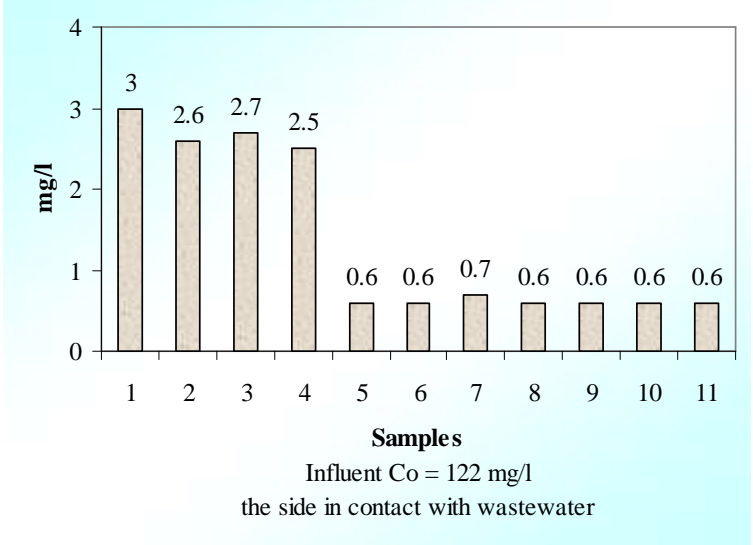

Figure 8: Effluent $\mathrm{Cd}^{2+}$ concentration, the side in contact with wastewater 


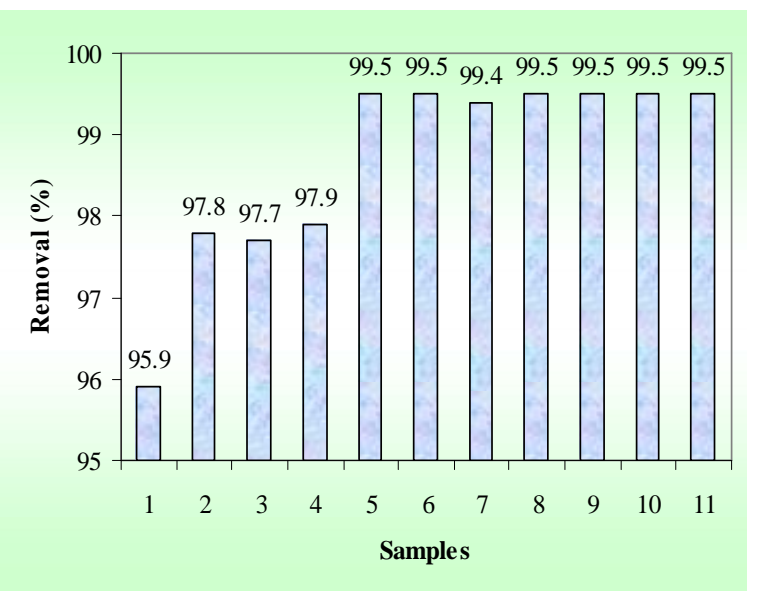

Figure 9: Removal efficiency of $\mathrm{Cd}^{2+}$, the side in contact with wastewater

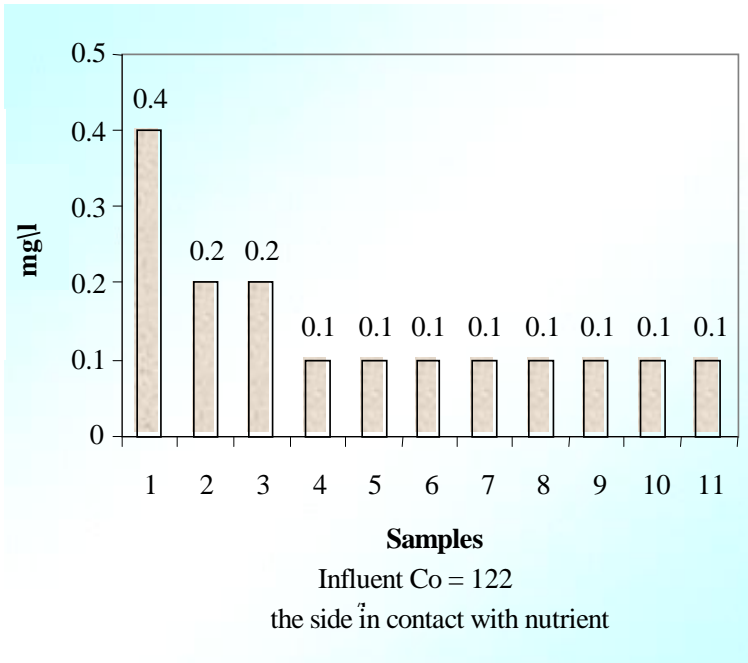

Figure 10: Effluent $\mathrm{Cd}^{2+}$ concentration, the side in contact with nutrient

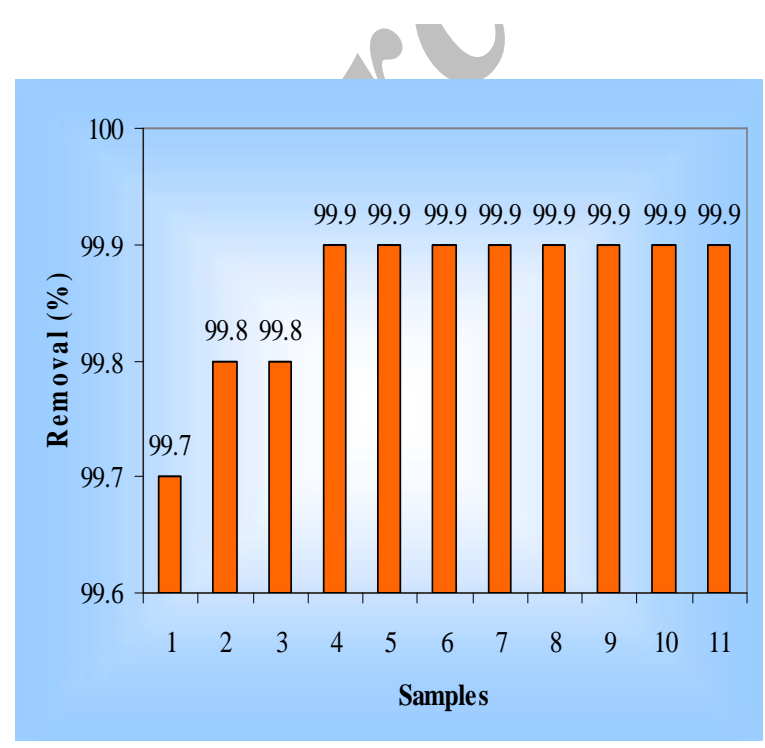

Figure 11: Removal efficiency of $\mathrm{Cd}^{2+}$, the side in contact with nutrient
Upon this bacterial growth, the decontamination of heavy metals especially $\mathrm{Cd}^{2+}$ from influent wastewater can be achieved. Chromate, copper, and cobalt. Alcaligenes eutrophus $\mathrm{CH} 34$ has the capabilities in being resistance to many metals by mutations as reported for several systems such as mercury, arsenic and antimony, Also, the decontamination of mixed sources of pollution having different concentrations of heavy metals and organic xenobiotics is possible with high efficiencies. Obtaining about 99 percent reduction in $\mathrm{Cd}^{2+}$ concentration of polluted wastewater in this research is vary interesting and therefore can be applied for similar industrial wastewater.

The bioremediation of polluted soils is smother application of Alcaligenes eutrophus CH34.The development of these areas in fullscale commercial projects and applications needs a great multipurpose approach from molecular genetics and physiology biotechnology and biochemical engineering.

\section{Acknowledgements}

The Student Scholarships Office of Ministry of Health with cooperation of the Felemish Institute of Technological Research V.I.T.O., Mol, and Belguim generously helped this research during the sabbatical leave period of this first author.

\section{References}

Collard, J. M., A. Provoost, S. Taghavi, and M. Mergeay, A new type of Alcaligenes eutrophus CH34 zinc resistance generated by mutations affecting regulation of the cnr cobalt-nickel resistance system, J. of bacteriology. 779-784, 1993

Collard, J. M., P. Corbisier, L. Diels, Q. Dong, C. Jeanthon, M. Mergeay, S. Taghavi, D. van der Lelie, A. Wilmotte and S. Wuertz, Plasmid for heavy metal resistance in Alcaligenes eutrophus CH34: mechanisms and applications, FEMS Microbio. Reviews, 405-414, 1994

Cooksey, D. A., Copper uptake and resistance system in bacteria. Mol. Microbiol. 7, 1-5, 1993

Diels, L., Accumulation and precipitation of $C d$ and $\mathrm{Zn}$ ions by Alcaligenes eutrophus strains. Biohydrometallurgy Editors J. Salley, R. G. L. McCready, P. Z. Wichlacz, 369-377, 1990

Diels, L., and M. Mergeay, DNA probe mediated detection of resistance bacteria from soils with 
highly polluted by heavy metals. Appl. Environ. Microbiol. 56, 1485 1491, 1990

Diels, L., S. Van Roy, S. Taghavi, W. Doyen, R. Leysen, and $M$. Mergeay, The Use of Alcaligenes eutrophus immobilized in a tubular membrane reactor for heavy metal recuperation. Biohydrometallurgy Meeting, Jackson Hole, 2225, 1993

Diels, L., S. Van Roy, M. Mergeay, W. Doyen, S. Taghavi, R. Leysen, Immobilization of bacteria in composite membranes and development of tubular membrane reactors for heavy recuperation. Un megaplasmide de resistance aux metaux lourds, d'alcaligenes eutrophus, 275-293, 1996.

Michel L. J., L. E. Macaskie and A. C. R. Dean, Cadmium accumulation by immobilized cell of a citrobacter sp., using various phosphate donors. Biotechnol. Bioeng. XXVII, 1358-1365,1986

Nies, D. H., A. Nies, L. Chu and S. Silver, Expression and nucleotide sequence of a plasmid-determined divalent cation efflux system from Alcaligenes eutrophus. Proc, Nat., Acad. Sci. USA, 86, 7351735,1989 